\title{
Genesis and solvus relations of submicroscopically intergrown paragonite and phengite in a blueschist from northern California *
}

\author{
Yen-Hong Shau, Melanie E. Feather**, Eric J. Essene, and Donald R. Peacor \\ Department of Geological Sciences, The University of Michigan, Ann Arbor, MI 48109, USA
}

Recived February 12, 1990 / Accepted July 13, 1990

\begin{abstract}
Electron microbeam techniques have been used to examine submicroscopically intergrown paragonite, phengite and chlorite from the South Fork Mountain Schist of the Franciscan Terrane of northern California, which was subjected to blueschist facies metamorphism. The sample also contains quartz, albite, lawsonite, and rutile. The subassemblage albite-lawsonite-rutile requires metamorphic conditions on the low-temperature side of the equilibrium albite + lawsonite + rutile $=$ paragonite + sphene + quartz $+\mathrm{H}_{2} \mathrm{O} \quad\left(\mathrm{T}<200^{\circ} \mathrm{C}\right.$ and $\mathrm{P}<$ 7.4 kbars based on thermodynamic data of Holland and Powell 1990). The white micas appear to be optically homogeneous, but back-scattered electron images can distinguish two different micas by their slight difference in contrast. Electron microprobe analyses (EMPA) of micas show $\mathrm{Na} /(\mathrm{Na}+\mathrm{K})$ ranging from 0.2 to 0.8 . The two micas are resolved by transmission electron microscopy (TEM) as packets of phengite and paragonite that range from 20 to several hundred $\mathrm{nm}$ in thickness. The compositions, determined by analytical electron microscopy (AEM), constrain the limbs of the phengite-paragonite solvus to values of $\mathrm{Na} /(\mathrm{Na}+\mathrm{K})=<0.02$ and 0.97 , representing less mutual solid solution than ever reported by EMPA. The textural relations imply that the sheet silicates were derived from reactions between fluids and detrital clays and that they are in an intermediate stage of textural development. We caution that microprobe analyses of apparently homogeneous sheet silicates may yield erroneous data and lead to faulty conclusions using phengite barometry and paragonite-muscovite thermometry, especially in fine-grained rocks that formed at relatively low temperatures.
\end{abstract}

\footnotetext{
* Contribution no. 473 from the Mineralogical Laboratory, Department of Geological Sciences, The University of Michigan, Ann Arbor, Michigan, USA

** Current address: Smithsonian Institution, Conservation Analytical Laboratory, Museum Support Center, Washington, D.C. 20560 , USA

Offprint requests to: Y.H. Shau
}

\section{Introduction}

Coexisting paragonite and muscovite (or phengite) have been analyzed in prograde metamorphic assemblages in the anchizone to epizone (Frey 1970, 1978; Livi et al. 1988), in the pumpellyite facies (including prehnite-pumpellyite and pumpellyite-actinolite facies, term from Essene 1989; occurrences from Kramm 1980; Merriman and Roberts 1985; Pe-Piper 1985), the albite-epidote hornfels facies (Okuyama-Kusunose 1985), the greenschist facies (Höck 1974; Katagas and Baltatzis 1980; Ashworth and Evirgen 1984; Baltatzis and Sideris 1985), the amphibolite facies (Burnham and Radoslovich 1964; Zen and Albee 1964; Henley 1970; Baltatzis and Wood 1977; Nakamura and Kihara 1977; Thompson et al. 1977; Hoffer 1978; Laird and Albee 1981; Enami 1983; Frank 1983; Grambling 1984; Droop 1985; Guitard 1987), the blueschist facies (Banno 1964; Makanjuola and Howie 1972; Black 1975; Okrusch et al. 1978; Mposkos and Perdikatzis 1981; Munha et al. 1984; Ridley 1984; Ghent et al. 1987), and in eclogite facies (Ahn et al. 1985 and references therein; Gil Ibarguchi and Ortega Girones 1985; Menot and Seddoh 1985; Brown and Forbes 1986; Sandrone et al. 1986; Godard 1988; Schliestedt and Okrusch 1988; Mposkos 1989; Droop et al. 1990; Mottana et al. 1990). The phengitic substitution in muscovite has been used as a barometer (Velde 1965; Massonne and Schreyer 1987) and the miscibility of paragonite in muscovite as a thermometer (Henley 1970; Eugster et al. 1972; Baltatzis and Wood 1977; Baltatzis and Sideris 1985; Chatterjee and Flux 1986). The width of the muscovite-paragonite solvus varies with temperature, but its exact T-X position remains uncertain (Essene 1989) despite much experimental data and thermodynamic modeling (Eugster et al. 1972; Blencoe 1974; Chatterjee and Froese 1975; Pascal and Roux 1985; Chatterjee and Flux 1986; Flux and Chatterjee 1986; Green and Usdansky 1986). In order to define the solvus width for different metamorphic conditions, the compositions of the minerals must be accurately determined, but sheet silicates may be intergrown on such 
a fine scale that chemical analyses using the electron microprobe may include more than one phase (Albee and Chodos 1965; Höck 1974; Cruickshank and Ghent 1978; Mohr and Newton 1983; Franceschelli et al. 1986; Shau et al. 1990). X-ray diffraction studies (Frey 1969; Mohr and Newton 1983; Merriman and Roberts 1985) imply that paragonite and phengite are submicroscopically intergrown, and such intergrowths have been directly imaged using transmission electron microscopy (Ahn et al. 1985; Livi et al. 1988).

In this study intergrowths of phengite, paragonite and chlorite in a blueschist facies rock have been examined in order to determine the scale of the intergrowths and the miscibility of paragonite in phengite for comparison with previous work on coexisting paragonite and phengite from a Franciscan gneissic eclogite (Ahn et al. 1985). The sample used for this study is a quartz-albitechlorite-mica schist (metagreywacke) from the South Fork Mountain Schist, part of the Pickett Peak Terrane of the eastern Franciscan Belt of northern California, which was metamorphosed in the blueschist facies. Brown and Ghent (1983) found lawsonite, aragonite, crossitic amphiboles and minor sodic pyroxenes with 10 $30 \mathrm{~mol} \%$ jadeite in the Ball Rock and Black Butte areas of the South Fork Mountain Schist, and they estimated peak metamorphic pressures and temperatures to be in the vicinity of $6-8 \mathrm{~kb}$ and $270-310^{\circ} \mathrm{C}$. Jayko et al. (1986) reported aragonite, crossite, and some coexisting paragonite and phengite in the South Fork Mountain Schist, and they provided the paragonite-bearing samples for this study. They concluded that the area has undergone three periods of deformation, with blueschist facies conditions occurring during the first two. Jayko et al. (1986) estimated that these rocks were subjected to a maximum temperature of $330-350^{\circ} \mathrm{C}$ and pressures of $7-9 \mathrm{~kb}$, based on oxygen isotope ratios and mineral phase equilibria.

\section{Methods and results}

\section{Petrography}

Thin sections of the sample 82-RRJ-39a (chosen as it contains significant amounts of paragonite coexisting with phengite based on the XRD analyses) show thicker quartz-rich bands alternating with thinner micaceous strips of white micas and chlorite (cf. BSE images in Figs. 1 and 2). The sample consists of very fine-grained $\left(10-20 \mu \mathrm{m}\right.$ in diameter) granular quartz and albite $\left(\mathrm{Ab}_{97.6}\right.$ $\mathrm{An}_{0.2} \mathrm{Or}_{2.2}$ ), larger detrital grains of quartz and albite (up to several hundred $\mu \mathrm{m}$ in diameter), tablets of chlorite and white micas, and accessory euhedral lawsonite $\left(\mathrm{Ca}_{0.9} \mathrm{Al}_{2.0} \mathrm{Fe}_{<0.1} \mathrm{Si}_{2.0} \mathrm{O}_{7}(\mathrm{OH})_{2}\right.$. $\mathrm{H}_{2} \mathrm{O}$ ), rutile, zircon, tourmaline, apatite, pyrite, ill-defined iron oxide minerals, and graphitic materials.

Petrographically, the white micas appear to consist of a single phase. Two kinds of chlorite can be distinguished by their textures: one occurring as thin laths oriented in the plane of foliation, and the other forming porphyroblasts with cleavages at a large angle to foliation (Fig. 2). Both kinds of chlorite are pale yellowish-green and show weak birefringence under plane-polarized light. They are length-slow, have a negative optic sign, and display grey or abnormal blue interference colors. Some grains of mica contain thin layers of chlorite that may be identified by their low birefringence. Some intimate intergrowths of chlorite-micas are yellowish

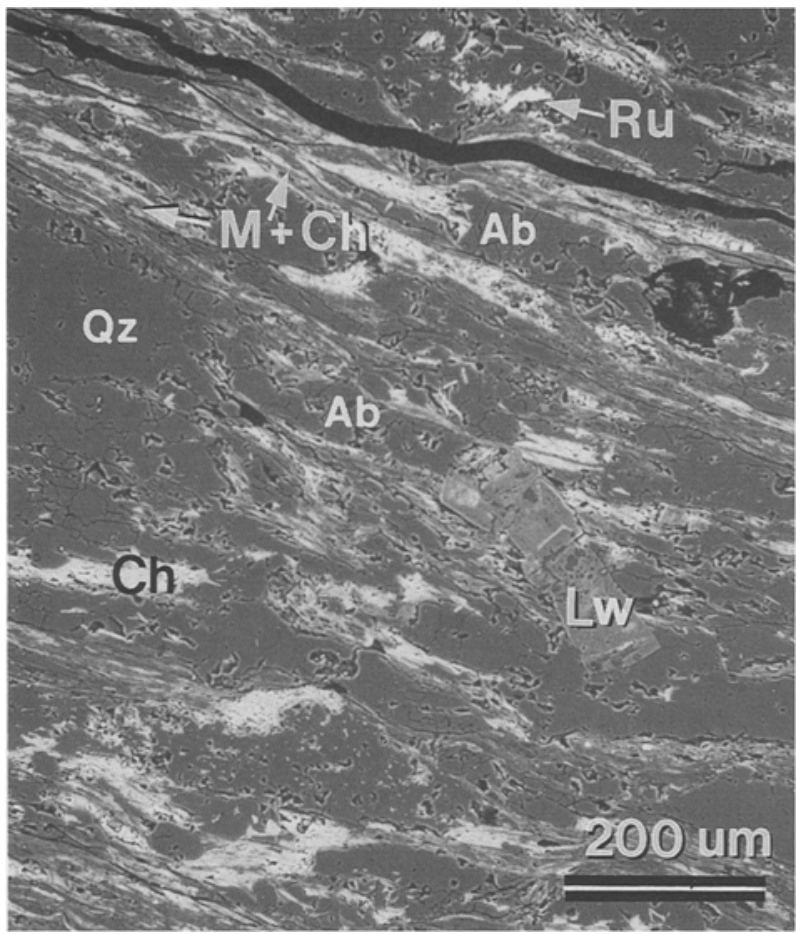

Fig. 1. SEM back-scattered electron (BSE) image showing the general textural relations of the sample. $A b$, Albite; $C h$, chlorite; $L w$, lawsonite; $M$, micas; $Q z$, quartz; $R u$, rutile

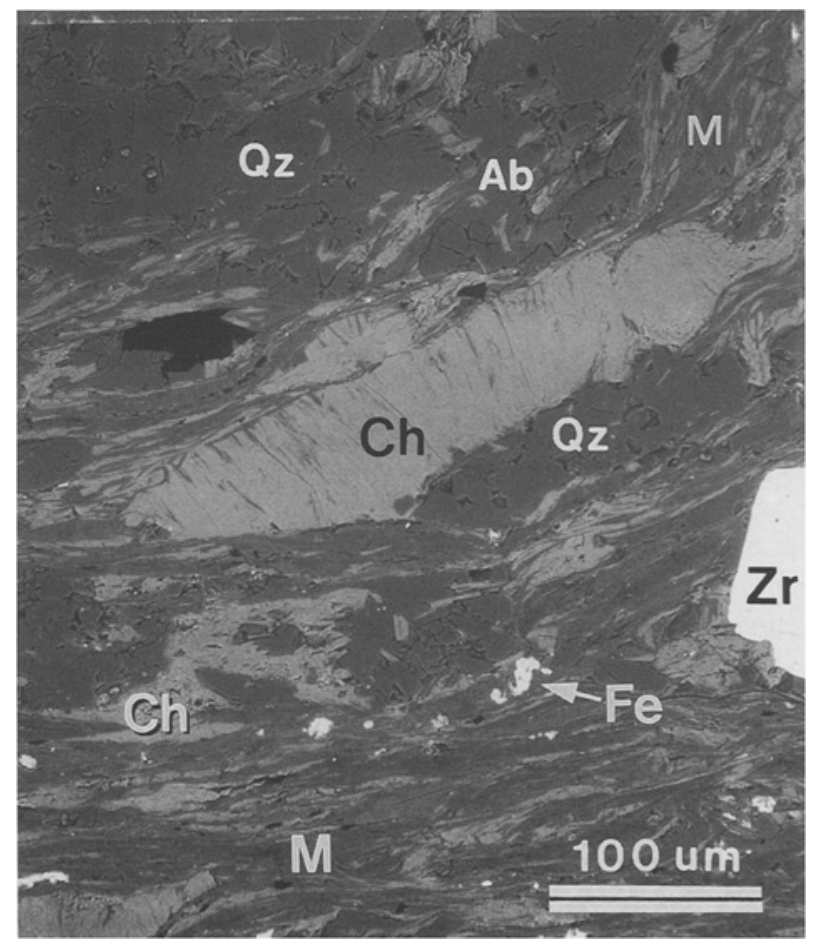

Fig. 2. SEM BSE image showing chlorite porphyroblasts and laths intercalated with micas. $F e$, Iron oxides; $Z r$, zircon; other abbreviations are the same as in Fig. 1 
brown, similar to the submicroscopically intercalated chlorite and muscovite described by Franceschelli et al. (1986).

\section{Scanning electron microscopy (SEM)}

A Hitachi S-570 SEM with a back-scattered electron detector was utilized to examine the textural relationships on a finer scale than that attainable optically. Back-scattered elcctron (BSE) images of the mica-rich areas showcd two shades of grey, suggesting the presence of two phases rather than a single phase (Fig. 3). Some of these mica grains had either high $\mathrm{K} / \mathrm{Na}$ or high $\mathrm{Na} / \mathrm{K}$ ratios when qualitatively analyzed by energy dispersive spectrometry (EDS) on the SEM. Although domains of each of the two micas appear to be up to a few $\mu \mathrm{m}$ in size (Fig. 3), the vast majority of EDS analyses of the micas showed high concentrations of both $\mathrm{K}$ and $\mathrm{Na}$, indicating the presence either of very fine-grained intcrgrowths of the two micas, or of one micaceous phase with an intermediate composition. Chlorite grains were usually large enough to bc analyzed without beam overlap onto other phases, but there were several instances when EDS spectra and BSE images suggested the presence of chlorite intimately intergrown with the micas (Figs. 1-3).

\section{$X$-ray diffraction $(X R D)$}

Paragonite and phengite were observed in sample $82-$ RRJ-39a by Jayko et al. (1986) using XRD. We also obtained powder diffraction patterns from the same sample using an automated Philips $\mathrm{X}$-ray diffractometer with $\mathrm{CuK}$ radiation and a graphite monochrometer. Quartz was used as an internal standard. The X-ray

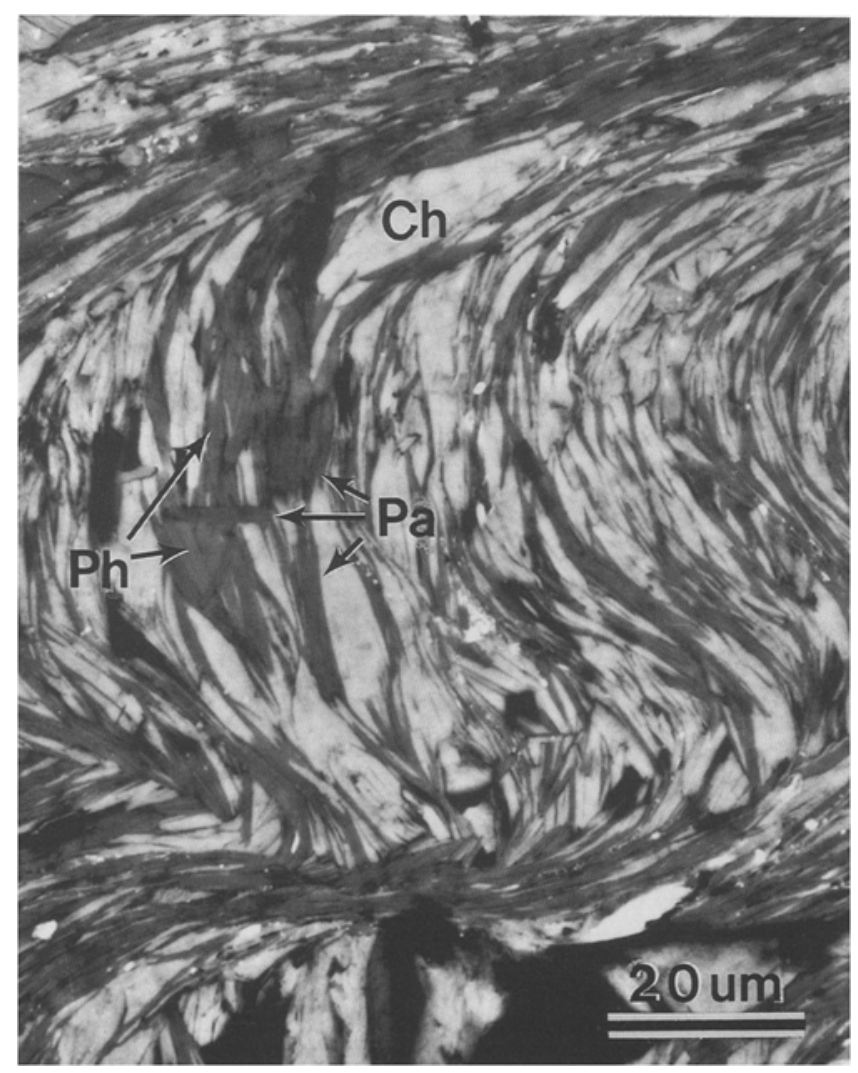

Fig. 3. SEM BSE image showing an area of two intergrown micas and chlorite parallel to the rock foliation. Paragonite $(P a)$ is darker grey, phengite $(P h)$ is lighter grey, and chlorite $(C h)$ is white powder patterns indicated the presence of both paragonite and phengite with the former similar to a $2 \mathrm{M}_{1}$-polytype paragonite (Chatterjee 1970). Diffraction peaks were observed at 0.965 and $0.998 \mathrm{~nm}$ for $\mathrm{d}_{(002)}, 0.481$ and $0.497 \mathrm{~nm}$ for $\mathrm{d}_{(004)}$, and 0.321 and $0.334 \mathrm{~nm}$ for $\mathrm{d}_{(006)}$ (for $2 \mathrm{M}$ micas). There are no reflections between 0.481 and $0.497 \mathrm{~nm}$ or between 0.321 and $0.334 \mathrm{~nm}$. Such reflections would indicate the presence of a mixed-layer paragonite/ phengite (Frey 1969). In addition, diffraction peaks for quartz, albite and chlorite were present.

\section{Electron microprobe analysis (EMPA)}

Polished thin sections of the sample were studied using wavelength and energy dispersive spectrometry (WDS and EDS) on a fully automated CAMECA Camebax electron microprobe. Various operating conditions were investigated, including reducing the accelerating voltage to $6 \mathrm{kV}$ and scanning over a one to five $\mu \mathrm{m}$ square area, to reduce diffusion of the alkali elements $\mathrm{K}$ and $\mathrm{Na}$. Rapid local loss of these elements at $6 \mathrm{kV}$ occurred after as little as five seconds when using a focused electron beam. With a $5 \mu \mathrm{m}$ squarearea beam and counting times of $50 \mathrm{sec}$ at $6 \mathrm{kV}$, there was no loss of alkalis owing to diffusion, but the microprobe beam overlapped onto minerals other than those to be analyzed, resulting in heterogenous compositions from portions of paragonite, phengite and chlorite (Tables 1,2). The analyses, when compared with the analyses obtained by analytical electron microscopy (AEM) as shown later, indicate that phengite and paragonite arc intcrlayered on a scale so small (less than $1 \mu \mathrm{m}$ diameter) that EMPA averages the two phases and gives risc to intermediate compositions. Chlorite and Fe of micas were analyzed separately at $12 \mathrm{kV}$.

Table 1. Selected electron microprobe analyses of white micas ${ }^{\text {A }}$

\begin{tabular}{|c|c|c|c|c|c|c|c|c|}
\hline $\begin{array}{l}\text { Oxides } \\
(w t \%)\end{array}$ & 1 & 2 & 3 & 4 & 5 & 6 & 7 & 8 \\
\hline $\mathrm{SiO}_{2}$ & 50.4 & 49.8 & 49.8 & 47.3 & 49.5 & 46.2 & 48.0 & 54.9 \\
\hline $\mathrm{Al}_{2} \mathrm{O}_{3}$ & 29.6 & 29.2 & 31.4 & 30.6 & 33.0 & 30.7 & 34.2 & 24.9 \\
\hline $\mathrm{FeO}^{b}$ & 2.9 & 3.1 & 2.7 & 2.6 & 1.4 & 3.2 & 1.3 & 1.2 \\
\hline $\mathrm{MgO}$ & 2.4 & 2.5 & 2.0 & 3.1 & 1.4 & 2.3 & 1.2 & 1.3 \\
\hline $\mathrm{CaO}$ & 0.0 & 0.0 & 0.0 & 0.1 & 0.1 & 0.0 & 0.2 & 0.1 \\
\hline $\mathrm{Na}_{2} \mathrm{O}$ & 1.3 & 1.6 & 2.3 & 2.6 & 4.3 & 3.8 & 4.4 & 6.2 \\
\hline $\mathrm{K}_{2} \mathrm{O}$ & 7.6 & 7.1 & 6.0 & 4.5 & 4.5 & 3.2 & 2.7 & 2.5 \\
\hline $\mathrm{H}_{2} \mathrm{O}^{\mathrm{c}}$ & 4.5 & 4.5 & 4.6 & 4.6 & 4.6 & 4.5 & 4.6 & 4.5 \\
\hline \multirow[t]{2}{*}{ Sum } & 98.7 & 97.8 & 98.8 & 95.4 & 98.8 & 93.9 & 96.6 & 95.6 \\
\hline & \multicolumn{8}{|c|}{ No. of atoms on the basis of $6(\mathrm{IV}+\mathrm{VI})$ cations } \\
\hline $\mathrm{Si}$ & 3.31 & 3.30 & 3.25 & 3.15 & 3.24 & 3.13 & 3.16 & 3.78 \\
\hline $\mathrm{Al}^{\mathrm{IV}}$ & 0.69 & 0.70 & 0.75 & 0.85 & 0.76 & 0.87 & 0.84 & 0.22 \\
\hline $\mathrm{Al}^{\mathrm{VI}}$ & 1.60 & 1.58 & 1.66 & 1.55 & 1.79 & 1.57 & 1.81 & 1.80 \\
\hline $\mathrm{Fe}^{2+}$ & 0.16 & 0.17 & 0.15 & 0.14 & 0.08 & 0.18 & 0.07 & 0.07 \\
\hline $\mathrm{Mg}$ & 0.24 & 0.25 & 0.19 & 0.31 & 0.14 & 0.23 & 0.12 & 0.13 \\
\hline $\mathrm{Ca}$ & - & - & - & - & - & - & 0.01 & - \\
\hline $\mathrm{Na}$ & 0.17 & 0.21 & 0.29 & 0.34 & 0.55 & 0.50 & 0.56 & 0.83 \\
\hline K & 0.64 & 0.60 & 0.50 & 0.38 & 0.38 & 0.28 & 0.23 & 0.22 \\
\hline $\mathrm{OH}^{\circ}$ & 2.00 & 2.00 & 2.00 & 2.00 & 2.00 & 2.00 & 2.00 & 2.00 \\
\hline $\mathrm{O}$ & 9.87 & 9.84 & 9.84 & 9.68 & 9.94 & 9.66 & 9.86 & 9.73 \\
\hline $\mathrm{Na} /(\mathrm{Na}+\mathrm{K})$ & 0.20 & 0.26 & 0.37 & 0.47 & 0.59 & 0.64 & 0.71 & 0.79 \\
\hline
\end{tabular}

a $2 \sigma$ (from counting statistics) for $\mathrm{Al}$ and $\mathrm{Si}: 0.02 ; \mathrm{Fe}: 0.05-0.07$; $\mathrm{Mg}: 0.04-0.06 ; \mathrm{Na}: 0.05-0.09 ; \mathrm{K}: 0.09-0.15$

${ }^{b}$ All Fe calculated as FeO

${ }^{\circ} \mathrm{OH}$ and equivalent $\mathrm{wt} \% \mathrm{H}_{2} \mathrm{O}$ assumed to be stoichiometric 
Table 2. Selected electron microprobe analyses of chlorite ${ }^{a}$

\begin{tabular}{lcccccc}
\hline $\begin{array}{l}\text { Oxides } \\
(\mathrm{wt} \%)\end{array}$ & 1 & 2 & $3^{\mathrm{d}}$ & 4 & 5 & $6^{\mathrm{d}}$ \\
\cline { 1 - 6 } $\mathrm{SiO}_{2}$ & 26.2 & 26.3 & 28.3 & 24.9 & 25.7 & 28.5 \\
$\mathrm{Al}_{2} \mathrm{O}_{3}$ & 20.6 & 21.4 & 22.6 & 20.8 & 20.8 & 23.5 \\
$\mathrm{FeO}^{\mathrm{b}}$ & 29.1 & 28.8 & 28.7 & 28.8 & 28.2 & 25.7 \\
$\mathrm{MnO}$ & 0.56 & 0.57 & 0.51 & 0.51 & 0.52 & 0.43 \\
$\mathrm{MgO}$ & 12.4 & 12.5 & 12.0 & 11.3 & 12.2 & 11.7 \\
$\mathrm{CaO}$ & $<0.03$ & 0.03 & 0.03 & 0.07 & 0.08 & 0.06 \\
$\mathrm{Na}_{2} \mathrm{O}$ & $<0.03$ & 0.04 & 0.08 & $<0.03$ & $<0.03$ & 0.22 \\
$\mathrm{~K}_{2} \mathrm{O}$ & $<0.03$ & $<0.03$ & 0.16 & $<0.03$ & 0.07 & 0.35 \\
$\mathrm{H}_{2} \mathrm{O}^{\mathrm{c}}$ & 11.2 & 11.4 & 11.7 & 10.9 & 11.2 & 11.5 \\
$\mathrm{Sum}$ & 100.1 & 101.0 & 104.1 & 97.3 & 98.8 & 102.0 \\
\hline
\end{tabular}

No. of atoms on the basis of 10 total cations

\begin{tabular}{lccllll}
\hline $\mathrm{Si}$ & 2.79 & 2.78 & 2.90 & 2.74 & 2.77 & 2.96 \\
$\mathrm{Al}^{\mathrm{IV}}$ & 1.21 & 1.22 & 1.10 & 1.26 & 1.23 & 1.04 \\
$\mathrm{Al}^{\mathrm{VI}}$ & 1.38 & 1.44 & 1.63 & 1.43 & 1.42 & 1.83 \\
$\mathrm{Fe}^{2+}$ & 2.60 & 2.54 & 2.46 & 2.66 & 2.54 & 2.23 \\
$\mathrm{Mn}$ & 0.050 & 0.044 & 0.044 & 0.047 & 0.047 & 0.035 \\
$\mathrm{Mg}$ & 1.97 & 1.96 & 1.83 & 1.85 & 1.98 & 1.81 \\
$\mathrm{Ca}$ & - & 0.004 & 0.003 & 0.008 & 0.010 & 0.006 \\
$\mathrm{Na}$ & - & 0.007 & 0.016 & - & - & 0.044 \\
$\mathrm{~K}$ & - & - & 0.020 & - & 0.009 & 0.046 \\
$\mathrm{OH} \mathrm{I}^{\mathrm{c}}$ & 8.00 & 8.00 & 8.00 & 8.00 & 8.00 & 8.00 \\
$\mathrm{O}$ & 10.09 & 10.11 & 10.25 & 10.09 & 10.09 & 10.35 \\
$\mathrm{Fe} /(\mathrm{Fe}+\mathrm{Mg})$ & 0.57 & 0.56 & 0.57 & 0.59 & 0.56 & 0.55 \\
$\mathrm{Al}$ & 0.17 & 0.22 & 0.53 & 0.17 & 0.19 & 0.79 \\
\hline
\end{tabular}

Analyses 1-3: porphyroblastic chlorite with basal planes at a large angle to foliation; analyses 4-6: chlorite with basal planes parallel to foliation

a $2 \sigma$ (from counting statistics) for $\mathrm{Si}: 0.04 ; \mathrm{Al}: 0.02 ; \mathrm{Fe}: 0.08$; $\mathrm{Mn}$ : 0.007; Mg: 0.03; Ca: 0.001 ; $\mathrm{Na}$ and $\mathrm{K}: 0.001-0.004$

${ }^{\mathrm{b}}$ All Fe calculated as FeO

${ }^{\circ} \mathrm{OH}$ and equivalent wt $\% \mathrm{H}_{2} \mathrm{O}$ assumed to be stoichiometric

${ }^{d}$ High total and high alkali contents are due to submicroscopic intergrowths or mixed-layering of micas

The electron microprobe analyses of micas show a wide scatter in $\mathrm{Na} /(\mathrm{Na}+\mathrm{K})$ and low totals even when corrected for stoichiometric $\mathrm{H}_{2} \mathrm{O}$ (Table 1). The ratio $\mathrm{Na} /(\mathrm{Na}+\mathrm{K})$ is probably still reliable, because the only $\mathrm{Na}$ - and $\mathrm{K}$-bearing intergrown phases are paragonite and phengite, and the ratio reflects their relative proportions in the areas analyzed. The ratio is commonly ca. 0.5 , though it varies from $0.2-0.8$ and extends across the phengite-paragonite solvus without any apparent discontinuity (Fig. 4).

Microprobe analyses show no obvious differences between the two texturally distinct chlorites (Table 2). Most chlorite analyses do not have significant concentrations of $\mathrm{Na}, \mathrm{K}$ or $\mathrm{Ca}(<0.1 \mathrm{wt} \%)$, and the differences between octahedrally coordinated $\mathrm{Al}$ and tetrahedrally coordinated $\mathrm{Al}$ are small when structural formulae are normalized to 10 cations ( $\mathrm{Al}^{\mathrm{VI}}-\mathrm{Al}^{\mathrm{IV}}$ averages 0.15 ). Thirteen analyses of chlorite grains that appeared to be without submicroscopically intergrown micas have formulae with $\mathrm{Si}=2.77 \pm 0.05(2 \sigma), \mathrm{Si} /(\mathrm{Si}+\mathrm{Al})=0.51 \pm 0.01$, and $\mathrm{Fe} /(\mathrm{Fe}+\mathrm{Mg})=0.57 \pm 0.03$. Chlorite analyses with significant $\mathrm{Na}, \mathrm{K}$ and high totals (Table 2, analyses 3 and

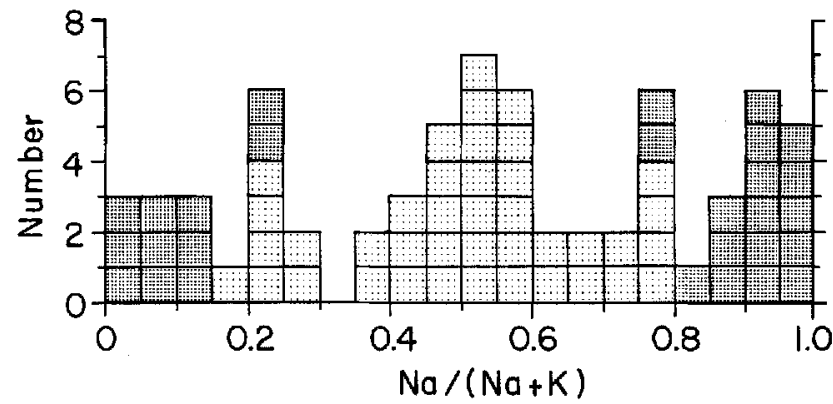

Fig. 4. Plot of $\mathrm{Na} /(\mathrm{Na}+\mathrm{K})$ for mica analyses of the blueschist sample. Lightly shaded areas correspond to EMPA and dark shaded areas to AEM analyses. The microprobe beam has integrated variable amounts of submicroscopically intergrown paragonite and phengite

6) are inferred to include submicroscopic intergrowths or mixed-layering of micas.

\section{Transmission electron microscopy (TEM)}

The TEM samples were prepared from sticky-wax-mounted thin sections by gluing aluminum washers of $3 \mathrm{~mm}$ diameter onto the micaceous areas. The specimens attached with washers were removed from the thin sections and further thinned with an ion mill until electron transparent edges were produced, and a light carbon coating was then applied. The rock sample that was used to prepare the thin sections for TEM specimens was cut perpendicular to foliation. Basal planes of sheet silicates could therefore be easily oriented parallel to the electron beam of the TEM with only minor tilting. The JEOL JEM-100CX and 2000FX, and Philips CM12 scanning transmission electron microscopes (STEMs) were used for this study.

Sheet silicates were identified through their characteristic $00 l$ diffraction patterns, $00 l$ lattice fringe images, and AEM analyses. Packets of layers for different phyllosilicates may also display differences in contrast and texture in TEM images. Figure 5 shows that phengite and paragonite occur as subparallel packets of layers. The packets vary from approximately $20 \mathrm{~nm}$ to several hundred $\mathrm{nm}$ in thickness. Paragonite and phengite can be differentiated by their different values of $d_{(002)}$ (ca. 0.96 and $1.00 \mathrm{~nm}$, respectively; Fig. 5) in selected area electron diffraction (SAED) patterns. Both paragonite and phengite display a characteristic "mottled" texture (Figs. 5, 6). Such a "mottled" texture was not observed in normal chlorite (Fig. 7). Ahn et al. (1986) showed that the "mottled" texture is due to beam damage, and that the degree of damage is different in $\mathrm{Na}, \mathrm{K}$, and $\mathrm{Ca}$ micas due to different rates of diffusion of cations. The paragonite also shows characteristic lenticular voids (or splitting of layers, see Figs. 5 and 6 ) as caused by beam damage, which are much more pronounced than those in phengite (cf. Ahn et al. 1986). These features were used as a first, tentative means of differentiating phengite and paragonite in TEM images.

Figure 6 displays a high-magnification image of intergrown paragonite and phengite packets in which $00 \mathrm{l}$ lattice fringes having spacings of ca. $1.0 \mathrm{~nm}$ and $2.0 \mathrm{~nm}$ can be observed. The AEM analyses from corresponding 

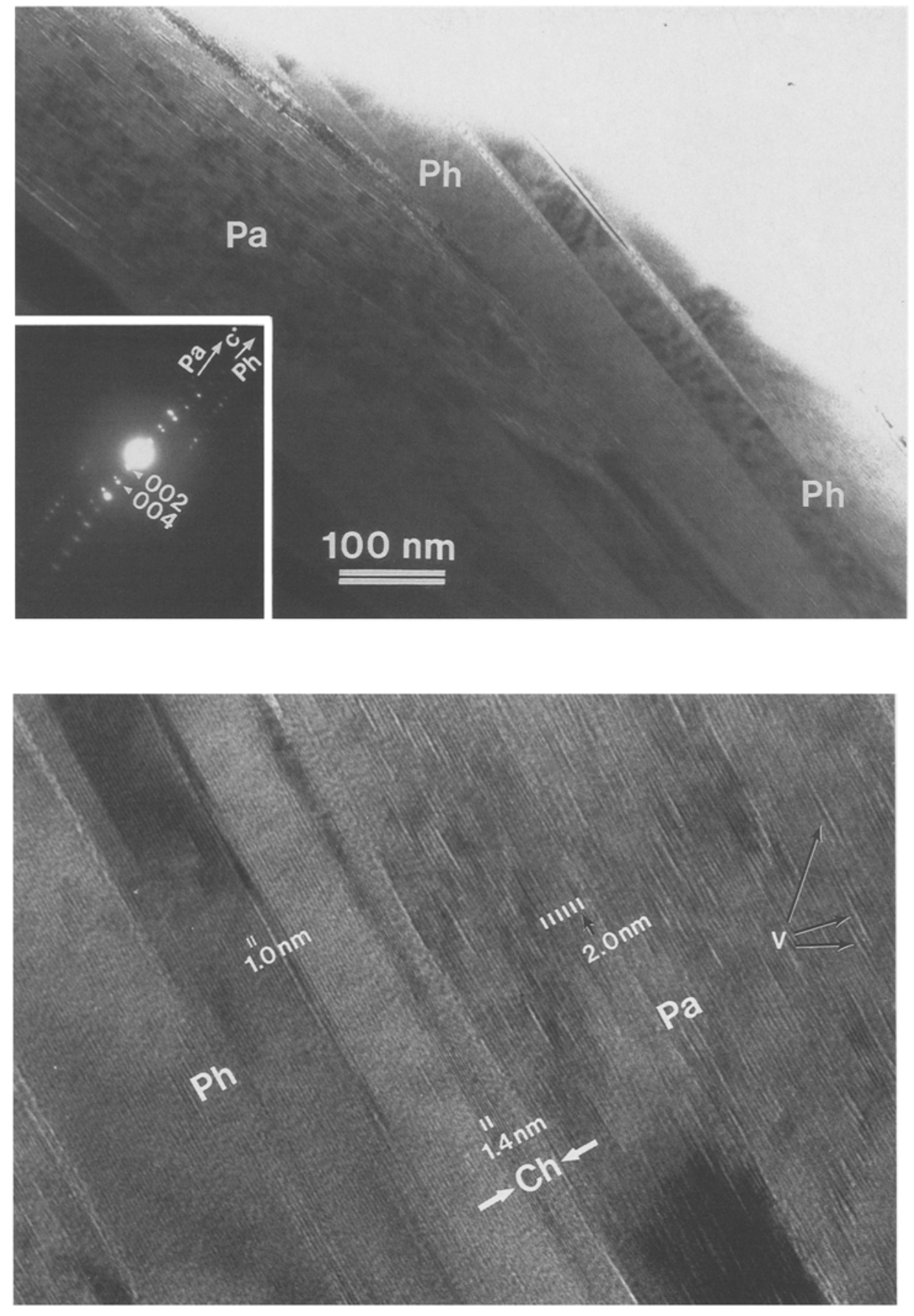

Fig. 5. TEM image showing subparallel intergrowth of paragonite $(P a)$ and phengite $(P h)$ packets. The "mottled" texture and split layers are more evident in paragonite than in phengite. Inserted SAED pattern shows two sets of 007 reflections from paragonite and phengite, respectively. The non- $00 l$ reflection parallel to $\mathrm{c}^{*}$ of paragonite, indicating a two-layer polytype
Fig. 6. TEM lattice fringe image showing parallel intergrowth of paragonite $(P a)$, phengite $(P h)$ and a thin $(\sim 5.0 \mathrm{~nm})$ packet of chlorite (Ch). 2-layer polytypism with $2.0 \mathrm{~nm}$ periodicity and abundant lenticular voids $(V)$ or layer splitting can be seen in the paragonite packet packets indicate the presence of both paragonite and phengite and not of one phase of an intermdiate composition. The separate paragonite and phengite packets are generally parallel or sub-parallel with contacts resembling small-angle grain boundaries (Fig. 5). Within individual packets the layer structure is relatively defect-free at the level of lattice fringe images, with layer terminations only rarely observed. Where polytypes could be identified, 2-layer and 3-layer polytypes were observed in both the paragonite and phengite (Figs. 5, 6). Ahn et al. (1985) found only the 2-layer polytype in phengite but 2- and 3-layer polytypes in paragonite in a blueschist eclogite.
Lattice fringe images of chlorite show that packets of layers range from less than one hundred to hundreds of $\mathrm{nm}$ thick and that some are intercalated with mica packets (Fig. 7). Most chlorite packets consists of welldefined $1.4 \mathrm{~nm}$ fringes that give normal chlorite compositions by AEM analyses. However, some packets are anomalous in that the lattice fringes display differences in contrast in alternate layers generally giving rise to a $2.8 \mathrm{~nm}$ periodicity (Fig. 8). Some of the lattice fringes in these anomalous packets exhibit periodicity ranging from 2.4 to $2.8 \mathrm{~nm}$. The contrast differences resemble those of two-layer polytypes but occur in images where the corresponding SAED patterns have only $00 l$ reflec- 


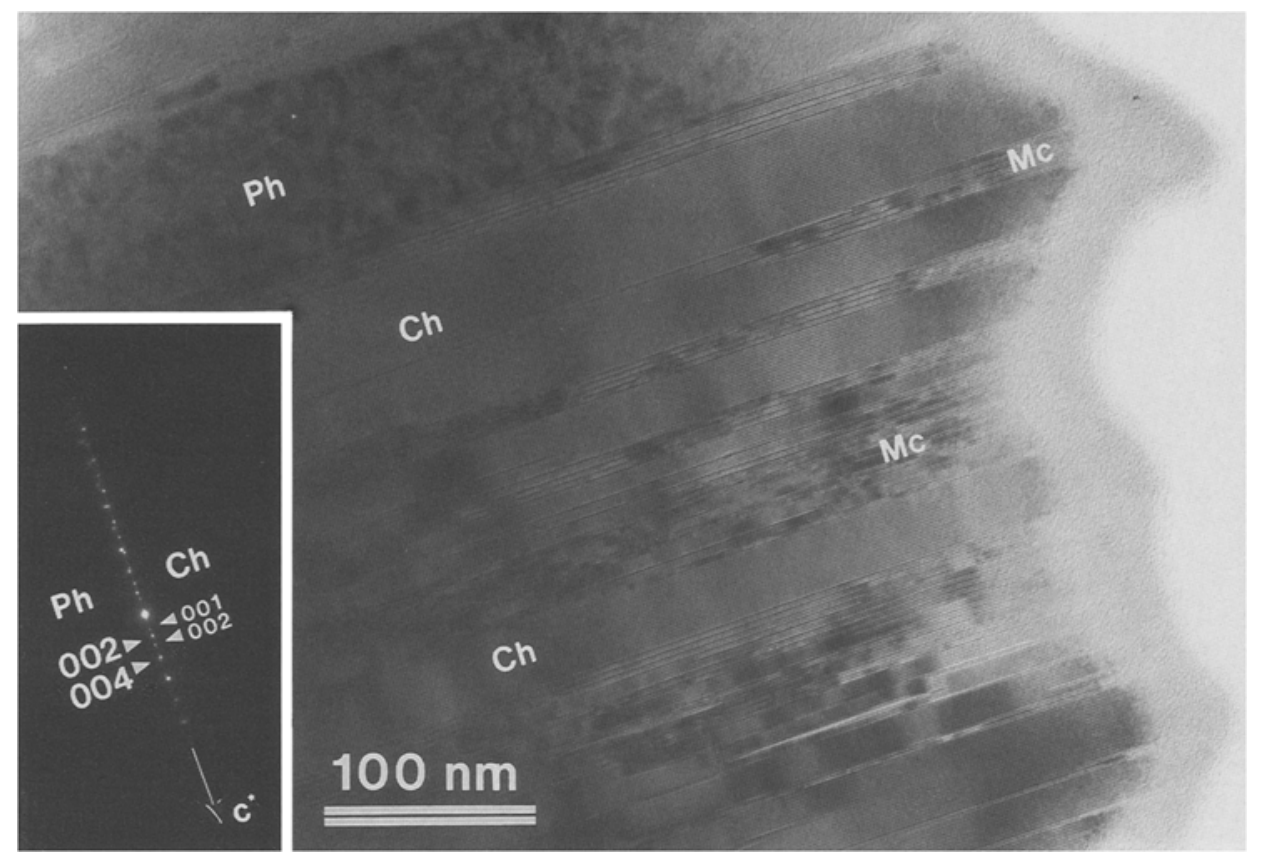

Fig. 7. TEM lattice fringe image showing a packet of phengite $(P h)$, packets of normal chlorite $(\mathrm{Ch})$ with well-defined $1.4 \mathrm{~nm}$ periodicity, and packets of anomalous chlorite $(\mathrm{Mc})$ which show a "mottled" texture and 2-layer $(\sim 2.8 \mathrm{~nm})$ periodicity. Inserted SAED pattern shows reflections from chlorite $\left(\mathrm{d}_{(001)}=\right.$ $1.4 \mathrm{~nm})$ and phengite $\left(\mathrm{d}_{(002)}=1.0 \mathrm{~nm}\right)$

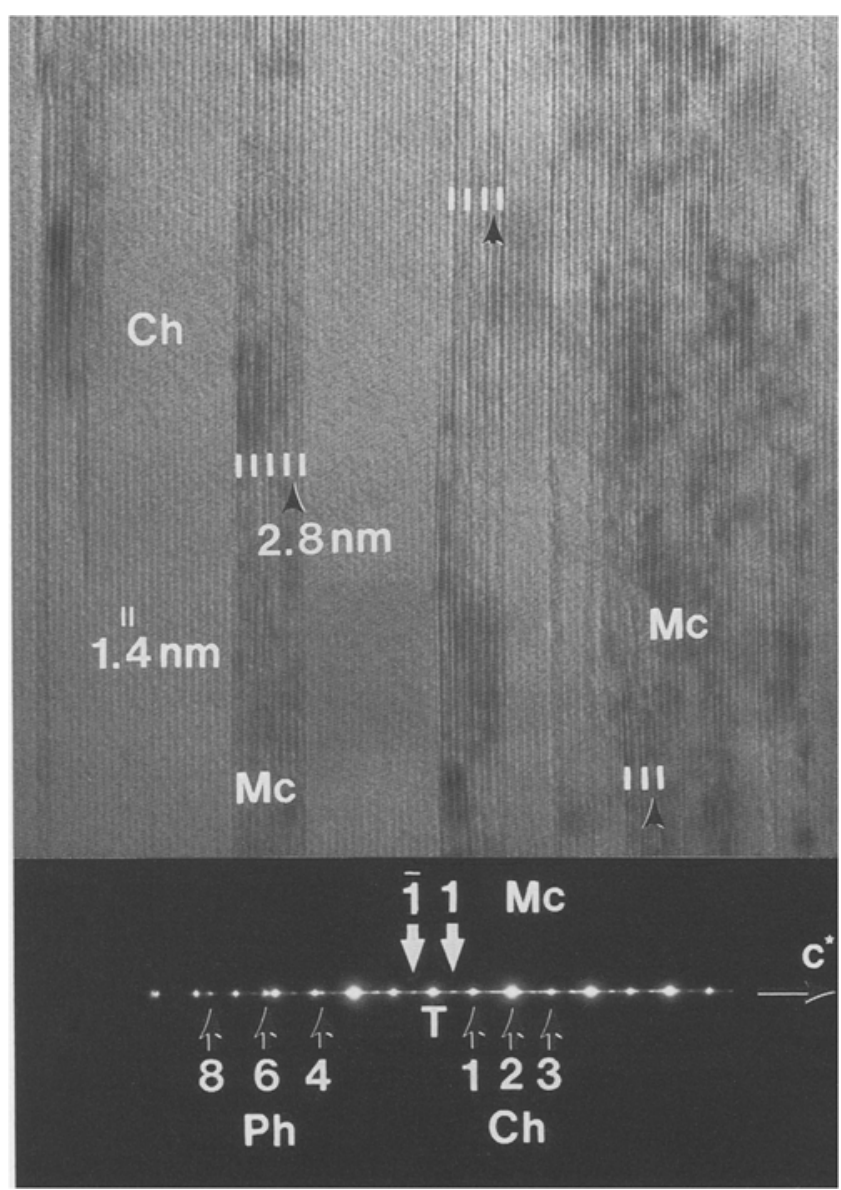

Fig. 8. An enlarged image from the central part of Fig. 7 showing $1.4 \mathrm{~nm}$ periodicity in chlorite $(C h)$ packets and $2.8 \mathrm{~nm}$ periodicity in anomalous chloritc $(M c)$ packcts. Inscrted SAED pattern showing $00 l$ reflections (numbers represent $l$ ) from chlorite, phengite $(P h)$, and anomalous chlorite which has $\mathrm{d}_{(001)}=2.8 \mathrm{~nm}$ (at the nodes indicated by white arrows). The streaking of reflections indicates stacking disorder in the anomalous chlorite tions (without non-00 $l$ reflections that give rise to definition of polytypes). The contrast differences must therefore be due to differences in composition and/or structure between layers. Packets of such layers display a "mottled" texture typical of micas that have undergone beam damage. These anomalous layers usually terminate and change to normal chlorite layers with $1.4 \mathrm{~nm}$ periodicity (Figs. 7, 8). The AEM analyses show $\mathrm{K}$ contents intermediate between those of mica and chlorite. These data imply the presence of a mixed-layer chlorite/mica, but such a phase has been observed many times by TEM and always shows $2.4(1.4+1.0) \mathrm{nm}$ periodicity (Lee et al. 1984; Ahn et al. 1988), in contrast to the present observations. This material is tentatively identified as being transitional from a precursor of mixed-layer chlorite/mica (probably 1:1 ordered) to chlorite, but its exact nature remains to be determined.

\section{Analytical electron microscopy ( $A E M$ )}

Quantitative EDS analyses were obtained with a Philips CM12 STEM and Kevex Quantum detector using the thin foil approximation and experimental $k$ values (Cliff and Lorimer 1975). The $k$ values were derived from standards of albite for $\mathrm{Na}$ and $\mathrm{Al}$, chlorite for $\mathrm{Al}, \mathrm{Mg}$ and $\mathrm{Fe}$, fayalite for $\mathrm{Fe}$, muscovite for $\mathrm{K}$ and $\mathrm{Al}$, sphene for $\mathrm{Ca}$, and rhodonite for $\mathrm{Mn}$, with all intensities being ratioed to that of Si. Relative concentrations of elements in a mineral, as derived from the analyses, were then used to calculate mineral formulae by normalization on the basis of cation numbers. Weight percents of oxides were calculated by normalization on the basis of anhydrous totals that wcre assumed to be $95.0 \%$ and $88.0 \%$ for micas and chlorite, respectively (Tables 3, 4). The deposit of metal onto TEM specimens from specimen washers (A1 in the present study) and specimen holders (made of Mo or Ta) during ion milling is a common source of contamination in AEM analysis. However, no detectable Mo or Ta for the studied specimens and no $\mathrm{Al}$ for the fayalite standard were observed when a Gatan 600 ion mill was used under the operating conditions of $6 \mathrm{kV}$ gun 
Table 3. Selected AEM analyses of white micas ${ }^{a}$

\begin{tabular}{|c|c|c|c|c|c|c|c|c|}
\hline \multirow{2}{*}{$\begin{array}{l}\text { Oxides } \\
(\text { wt } \%)\end{array}$} & \multicolumn{4}{|c|}{ Phengite } & \multicolumn{4}{|c|}{ Paragonite } \\
\hline & 1 & 2 & 3 & 4 & 5 & 6 & 7 & 8 \\
\hline $\mathrm{SiO}_{2}$ & 51.2 & 50.8 & 52.0 & 52.9 & 47.4 & 47.2 & 47.3 & 47.1 \\
\hline $\mathrm{Al}_{2} \mathrm{O}_{3}$ & 26.8 & 27.0 & 27.3 & 27.0 & 39.1 & 39.4 & 39.4 & 39.0 \\
\hline $\mathrm{FeO}^{\mathrm{b}}$ & 3.7 & 3.6 & 3.1 & 3.1 & 0.42 & 0.31 & 0.31 & 0.49 \\
\hline $\mathrm{MgO}$ & 3.4 & 3.8 & 3.8 & 3.8 & 0.62 & 0.70 & 0.61 & 0.40 \\
\hline $\mathrm{Na}_{2} \mathrm{O}$ & $<0.1$ & $<0.1$ & 0.5 & 0.5 & 6.3 & 6.9 & 6.8 & 7.7 \\
\hline $\mathrm{K}_{2} \mathrm{O}$ & 9.9 & 9.8 & 8.4 & 7.7 & 1.14 & 0.59 & 0.58 & 0.33 \\
\hline \multirow[t]{2}{*}{$\operatorname{Sum}^{\mathrm{c}}$} & 95.0 & 95.0 & 95.0 & 95.0 & 95.0 & 95.0 & 95.0 & 95.0 \\
\hline & \multicolumn{8}{|c|}{ No. of atoms on the basis of $6(\mathrm{IV}+\mathrm{VI})$ cations } \\
\hline $\mathrm{Si}$ & 3.38 & 3.34 & 3.38 & 3.41 & 3.00 & 2.98 & 2.99 & 3.00 \\
\hline $\mathrm{Al}^{\mathrm{IV}}$ & 0.62 & 0.66 & 0.62 & 0.59 & 1.00 & 1.02 & 1.01 & 1.00 \\
\hline $\mathrm{Al}^{\mathrm{vI}}$ & 1.46 & 1.43 & 1.37 & 1.46 & 1.92 & 1.91 & 1.93 & 1.93 \\
\hline $\mathrm{Fe}^{2+}$ & 0.21 & 0.20 & 0.17 & 0.17 & 0.022 & 0.016 & 0.016 & 0.026 \\
\hline $\mathrm{Mg}$ & 0.33 & 0.37 & 0.37 & 0.37 & 0.059 & 0.066 & 0.057 & 0.038 \\
\hline $\mathrm{Na}$ & - & - & 0.06 & 0.07 & 0.77 & 0.84 & 0.83 & 0.96 \\
\hline $\mathrm{K}$ & 0.84 & 0.82 & 0.69 & 0.64 & 0.092 & 0.048 & 0.047 & 0.027 \\
\hline \multicolumn{3}{|c|}{$\mathrm{Na} /(\mathrm{Na}+\mathrm{K})<0.02<0.02$} & 0.08 & 0.10 & 0.89 & 0.95 & 0.95 & 0.97 \\
\hline
\end{tabular}

a $2 \sigma$ (from counting statistics) for $\mathrm{Si}: 0.03-0.05 ; \mathrm{Al}: 0.01-0.02$; Fe: $0.002-0.01 ; \mathrm{Mg}: 0.006-0.02 ; \mathrm{Na}: 0.01-0.03 ; \mathrm{K}: 0.003-0.02$

${ }^{b}$ All Fe calculated as $\mathrm{FeO}$

${ }^{c}$ Oxides normalized to total $95.0 \mathrm{wt} \%$
Table 4. Selected AEM analyses of chlorite ${ }^{\text {a }}$

\begin{tabular}{|c|c|c|c|c|c|c|}
\hline $\begin{array}{l}\text { Oxides } \\
(w t \%)\end{array}$ & 1 & 2 & 3 & 4 & 5 & $6^{d}$ \\
\hline $\mathrm{SiO}_{2}$ & 26.3 & 25.5 & 25.6 & 24.9 & 26.1 & 29.3 \\
\hline $\mathrm{Al}_{2} \mathrm{O}_{3}$ & 19.5 & 20.3 & 20.9 & 20.3 & 18.7 & 20.1 \\
\hline $\mathrm{FeO}^{\mathrm{b}}$ & 29.7 & 30.6 & 29.3 & 30.3 & 31.8 & 25.9 \\
\hline $\mathrm{MnO}$ & 0.46 & 0.67 & 0.45 & 0.61 & 0.51 & 0.45 \\
\hline $\mathrm{MgO}$ & 12.0 & 10.9 & 11.8 & 11.9 & 10.9 & 10.1 \\
\hline $\mathrm{K}_{2} \mathrm{O}$ & - & - & - & - & - & 2.2 \\
\hline $\operatorname{Sum}^{c}$ & 88.0 & 88.0 & 88.0 & 88.0 & 88.0 & 88.0 \\
\hline
\end{tabular}

\begin{tabular}{lllllll}
\hline \multicolumn{7}{c}{ No. of atoms on the basis of 10} \\
\\
\hline $\mathrm{Si}$ & 2.85 & 2.78 & 2.76 & 2.70 & 2.85 & 3.16 \\
$\mathrm{Al}^{\mathrm{IV}}$ & 1.15 & 1.22 & 1.24 & 1.30 & 1.15 & 0.84 \\
$\mathrm{Al}^{\mathrm{VI}}$ & 1.33 & 1.39 & 1.41 & 1.29 & 1.26 & 1.71 \\
$\mathrm{Fe}^{2+}$ & 2.68 & 2.79 & 2.64 & 2.74 & 2.91 & 2.33 \\
$\mathrm{Mn}$ & 0.042 & 0.062 & 0.041 & 0.056 & 0.047 & 0.041 \\
$\mathrm{Mg}$ & 1.94 & 1.77 & 1.90 & 1.92 & 1.78 & 1.62 \\
$\mathrm{~K}$ & - & - & - & - & - & 0.30 \\
$\mathrm{Fe} /(\mathrm{Fe}+\mathrm{Mg})$ & 0.58 & 0.61 & 0.58 & 0.59 & 0.62 & 0.59 \\
$\mathrm{Al}$ & 0.18 & 0.17 & 0.17 & -0.01 & 0.11 & 0.87 \\
\hline
\end{tabular}

a $2 \sigma$ (from counting statistics) for $\mathrm{Si}: 0.03-0.04 ; \mathrm{Al}: 0.01-0.03$; Fe: 0.03-0.04; Mn: 0.004-0.006; Mg: 0.03-0.05; K: 0.01

${ }^{b}$ All Fe calculated as $\mathrm{FeO}$

- Oxides normalized to total $88.0 \mathrm{wt} \%$

d Anomalous chlorite consists of mixed-layered chlorite and micalike layers within an analyzed area that is only $20 \mathrm{~nm}$ wide across layers

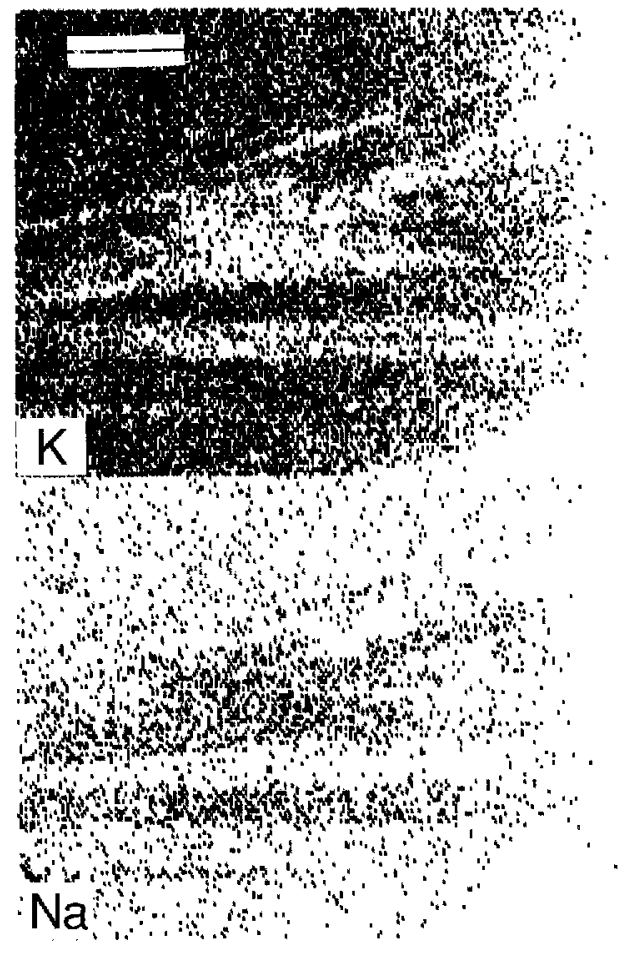

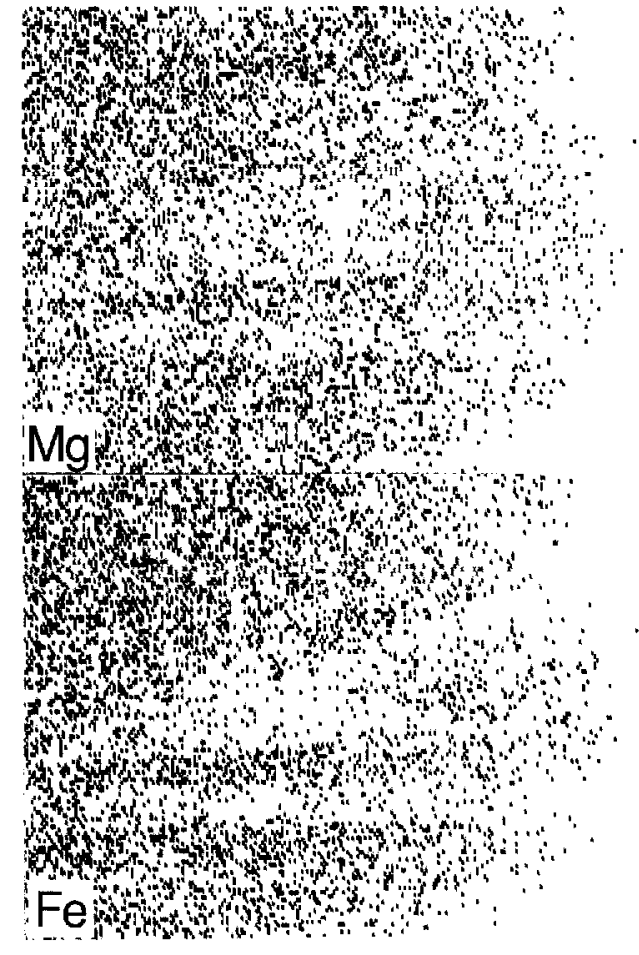

Fig. 9. AEM $X$-ray scanning images of an area with intergrown paragonite and phengite showing intensity contrast for $K_{\alpha}$ radiations of $\mathrm{K}, \mathrm{Mg}, \mathrm{Na}$, and Fe. The black dots corresponding to signals of characteristic X-ray lines. Paragonite packets can be seen most clearly as white subparallel laths in the $\mathrm{K}$ map. The scale bar is $1 \mu \mathrm{m}$ 
voltage, $0.7-1.0 \mathrm{~mA}$ gun current, and $15-20^{\circ}$ tilt angles. Contamination is therefore negligible. In order to account for diffusion of $\mathrm{K}$ and $\mathrm{Na}$, the analytical method of van der Pluijm et al. (1988) was used, wherein analytical conditions for standard and unknown are duplicated as closely as possible, especially with regard to count rate (or specimen thickness). Analyses were obtained by rastering the beam over areas ranging from $20 \times 20 \mathrm{~nm}^{2}$ to $1 \times 1 \mu \mathrm{m}^{2}$. Most analyses were obtained from areas for which electron diffraction appeared to imply the presence of a single phase.

Based on AEM analyses, the $\mathrm{Na} /(\mathrm{Na}+\mathrm{K})$ ratios of micas are generally either close to 0 or larger than 0.95 as shown in Table 3 . The single-phase packets (either paragonite or phengite) are up to several hundred nm thick (Fig. 5). However, intergrown paragonite or phengite packets of less than $20 \mathrm{~nm}$ in thickness must occur because many analyses over areas $20 \mathrm{~nm}$ wide across layers displayed variable, intermediate $\mathrm{Na} / \mathrm{Na}+\mathrm{K})$ ratios between 0.1 and 0.9 (Fig. 4). Paragonite-illite intergrowths on a $\leq 50 \mathrm{~nm}$ scale were also observed by Livi et al. (1988). Figure 9 is an X-ray map of intergrown paragonite and phengite. The contrast indicating relative concentrations of $\mathrm{K}, \mathrm{Mg}, \mathrm{Na}$, and $\mathrm{Fe}$, defines the texture of intergrown paragonite and phengite. The areas occupied by phengite clearly display uniformly high values of $\mathrm{Fe}$ and $\mathrm{Mg}$ in comparison to paragonite.

The AEM analyses of chlorite (Table 4) are in excellent agreement with the microprobe analyses of pure chlorite (Table 2), consistent with the relatively large sizes of some chlorite packets. On the other hand, even with a rastering area of $20 \times 20 \mathrm{~nm}^{2}$, AEM analyses of anomalous chlorite that exhibits the "mottled" texture (Figs. 7,8) have abnormally high $\mathrm{K}$ and/or $\mathrm{Na}$ contents and a significant excess of $\mathrm{Al}^{\mathrm{VI}}$ over $\mathrm{Al}^{\mathrm{IV}}$ when normalized to the chlorite formula (Table 4, analysis 6). This verifies that the electron microprobe analyses of chlorite that showed high $\mathrm{K}$ and $\mathrm{Na}$ contents, and that were apparently homogeneous at the optical scale, were obtained from areas that contain intergrown mica packets or mixed-layered mica-like layers.

\section{Discussion}

\section{Phase equilibria}

The sample contains no univariant assemblages that fix pressure and/or temperature, but several limiting assemblages constrain the conditions of formation. The presence of albite rather than jadeite + quartz indicates pressures less than 10 to $15 \mathrm{~kb}$ depending on temperature (Holland 1980). The equilibrium

albite + lawsonite $=$

$$
\text { clinozoisite + paragonite + quartz }+\mathrm{H}_{2} \mathrm{O}
$$

$\mathrm{NaAlSi}_{3} \mathrm{O}_{8}+4 \mathrm{CaAl}_{2} \mathrm{Si}_{2} \mathrm{O}_{7}(\mathrm{OH})_{2} \cdot \mathrm{H}_{2} \mathrm{O}=$

$2 \mathrm{Ca}_{2} \mathrm{Al}_{3} \mathrm{Si}_{3} \mathrm{O}_{12}(\mathrm{OH})+\mathrm{NaAl}_{2}\left(\mathrm{Si}_{3} \mathrm{Al}\right) \mathrm{O}_{10}(\mathrm{OH})_{2}+2 \mathrm{SiO}_{2}+6 \mathrm{H}_{2} \mathrm{O}$

(Holland 1979, 1988), limits temperature to less than 300 to $400^{\circ} \mathrm{C}$ depending on $\mathrm{P}\left(\mathrm{H}_{2} \mathrm{O}\right)$ (Fig. 10). In addition, a newly recognized equilibrium,

\footnotetext{
albite + lawsonite + rutile $=$$$
\text { paragonite }+ \text { sphene }+ \text { quartz }+\mathrm{H}_{2} \mathrm{O}
$$

$\mathrm{NaAlSi}{ }_{3} \mathrm{O}_{8}+\mathrm{CaAl}_{2} \mathrm{Si}_{2} \mathrm{O}_{7}(\mathrm{OH})_{2} \cdot \mathrm{H}_{2} \mathrm{O}+\mathrm{TiO}_{2}=$

$\mathrm{NaAl}_{2}\left(\mathrm{Si}_{3} \mathrm{Al}\right) \mathrm{O}_{10}(\mathrm{OH})_{2}+\mathrm{CaTiSiO}_{5}+\mathrm{SiO}_{2}+\mathrm{H}_{2} \mathrm{O}$,
}

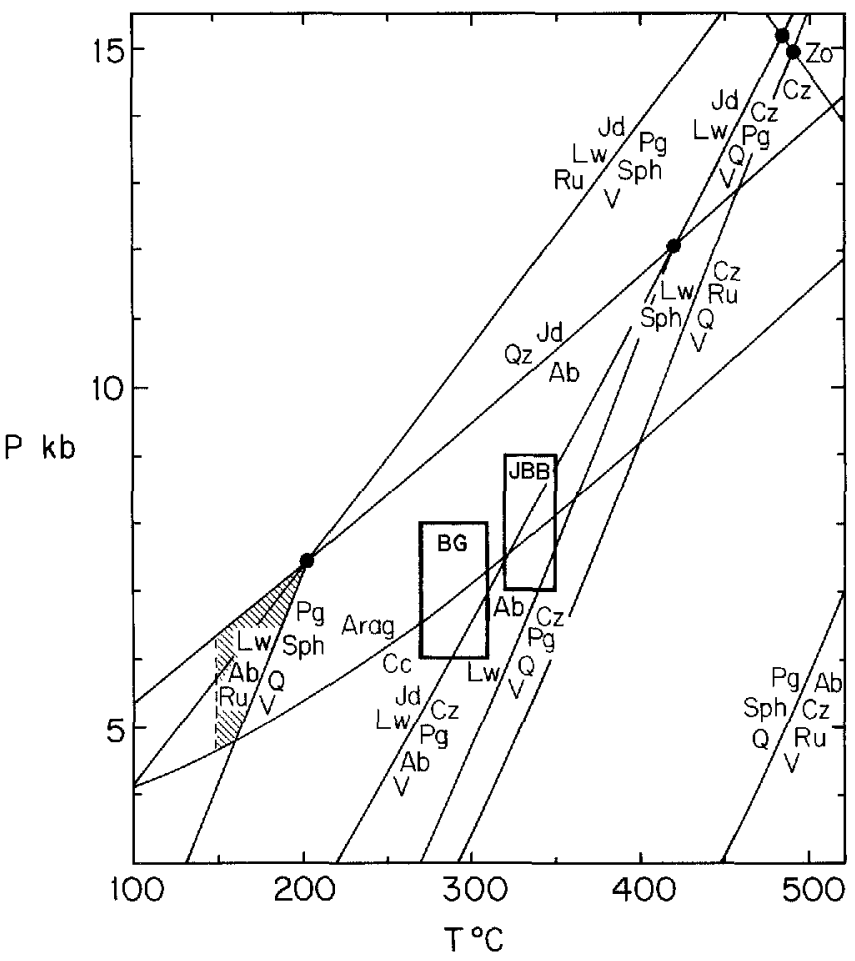

Fig. 10. Calculations of phase equilibria in the system $\mathrm{Na}_{2} \mathrm{O}-\mathrm{CaO}$ $\mathrm{Al}_{2} \mathrm{O}_{3}-\mathrm{TiO}_{2}-\mathrm{SiO}_{2}-\mathrm{H}_{2} \mathrm{O}\left(\mathrm{CO}_{2}\right)$ for the phases albite $(A b)$, jadeite $(J d)$, lawsonite $(L w)$, paragonite $(P g)$, zoisite $(Z o)$, clinozoisite $(C z)$, rutile $(R u)$, sphenc $(S p h)$, quartz $(Q)$, aragonite $($ Arag $)$, calcite $(C c)$ and $\mathrm{H}_{2} \mathrm{O}(V)$ using the Thermocalc program of Holland and Powell (1990). Low albite was used in the calculations. The diagonally lined area is the range of P-T consistent with the assemblage in sample 82-RRJ-39a. The P-T conditions for the South Fork Mountain schist estimated by Brown and Ghent (1983) are shown in the box labeled $B G$ and those of Jayko et al. (1986) are labeled $J B B$. Reactions involving analcite, stilbite and laumontite have been ignored on this diagram

will further constrain the upper temperature limit of formation of this rock, which includes the assemblage albite-lawsonite-rutile-paragonite-quartz without sphene. The locations of reaction (2), and its jadeite-bearing equivalent,

jadeite + lawsonite + rutile $=$ paragonite + sphene $+\mathrm{H}_{2} \mathrm{O}$ $\mathrm{NaAlSi}_{2} \mathrm{O}_{6}+\mathrm{CaAl}_{2} \mathrm{Si}_{2} \mathrm{O}_{7}(\mathrm{OH})_{2} \cdot \mathrm{H}_{2} \mathrm{O}+\mathrm{TiO}_{2}=$ $\mathrm{NaAl}_{2}\left(\mathrm{Si}_{3} \mathrm{Al}\right) \mathrm{O}_{10}(\mathrm{OH})_{2}+\mathrm{CaTiSiO}_{5}+\mathrm{H}_{2} \mathrm{O}$

have been calculated with a self-consistent data base of Holland and Powell (1990) (Fig. 10).

In addition, two other reactions:

lawsonite + sphene $=$ clinozoisite + rutile + quartz $+\mathrm{H}_{2} \mathrm{O}$

$$
\begin{aligned}
3 \mathrm{CaAl}_{2} \mathrm{Si}_{2} \mathrm{O}_{7}(\mathrm{OH})_{2} \cdot \mathrm{H}_{2} \mathrm{O}+\mathrm{CaTiSiO}_{5}= & \mathrm{CaI}_{2} \mathrm{Ca}_{2} \mathrm{Al}_{3} \mathrm{O}_{12}(\mathrm{OH})+\mathrm{TiO}_{2}+\mathrm{SiO}_{2}+5 \mathrm{H}_{2} \mathrm{O},
\end{aligned}
$$

and

$$
\begin{aligned}
& \text { paragonite }+ \text { sphene }+ \text { quartz }= \\
& \text { albite }+ \text { clinozoisite }+ \text { rutile }+\mathrm{H}_{2} \mathrm{O}
\end{aligned}
$$

$3 \mathrm{NaAl}_{2}\left(\mathrm{Si}_{3} \mathrm{Al}\right) \mathrm{O}_{10}(\mathrm{OH})_{2}+4 \mathrm{CaTiSiO}_{5}+2 \mathrm{SiO}_{2}=$ $3 \mathrm{NaAlSi}_{3} \mathrm{O}_{8}+2 \mathrm{Ca}_{2} \mathrm{Al}_{3} \mathrm{Si}_{3} \mathrm{O}_{12}(\mathrm{OH})+4 \mathrm{TiO}_{2}+2 \mathrm{H}_{2} \mathrm{O}$

have also been located (Fig. 10) and should be useful in higher temperature blueschist and greenschist facies 
rocks. For comparison, the equilibria jadeite + quartz $=$ albite, and aragonite $=$ calcite have also been calculated The resultant constraints on P-T for rock 82-RRJ-39a appear to be $<7.4 \mathrm{~kb}$ and $<200^{\circ} \mathrm{C}$ (diagonally lined area in Fig. 10). These temperatures are $100-150^{\circ} \mathrm{C}$ lower than estimates of Brown and Ghent (1983) and Jayko et al. (1986), which are based primarily on oxygen isotope thermometry. Either reaction (2) is mislocated, the rutile may not have equilibrated with lawsonite and albite in the rocks, or the quartz-magnetite pairs used in the isotope thermometry may not have equilibrated. Brown and Ghent (1983) reported sphene but no rutile in their lawsonite-bearing samples of South Fork Mountain Schist at Black Butte and Ball Rock areas, but we have identified no sphene in the paragonite-bearing samples provided by Jayko et al. (1986). The preservation of aragonite in the South Fork Mountain Schists implies that the rocks cooled to $<180^{\circ} \mathrm{C}$ before the cooling path dropped into the calcite field (Carlson and Rosenfeld 1981). This path is consistent with that suggested by the phase equilibria in Fig. 10 but is more difficult to reconcile with the peak P-T conditions of Brown and Ghent (1983) and of Jayko et al. (1986). Further thermometry is clearly needed to define formation conditions of these blueschists.

\section{Genesis of paragonite, phengite, and chlorite}

The results of this study show that packets of paragonite, phengite and chlorite layers are intergrown, with packets of each phase ranging from a few layers to several hundred $\mathrm{nm}$ in thickness. With the exception of some very fine-scale paragonite-phengite intergrowths and some anomalous chlorite, all three phases generally occur as well defined, discrete packets of layers having near end-member compositions. A few packets of single phases up to $2 \mu \mathrm{m}$ thick were observed. The heterogeneity in packet sizes and abundance of very small discrete packets imply that equilibrium of texture was not attained. However, the general textural relations provide insight into the formation conditions of paragonite and phengite in a prograde sequence.

Frey $(1970,1978)$ observed the following sequence from unmetamorphosed sediments through the anchizone: irregular mixed-layer illite/montmorillonite $\rightarrow$ regular mixed-layer mica/montmorillonite $\rightarrow$ mixed-layer paragonite/phengite $\rightarrow$ discrete paragonite and phengite, as consistent with increasing modal abundance of paragonite with metamorphic grade. Chatterjee (1973) proposed the reaction Na-montmorillonite + albite $=$ paragonite + quartz $+\mathrm{H}_{2} \mathrm{O}$ at temperatures and pressures similar to those of the South Fork Mountain Schist. Jayko et al. (1986) suggested that paragonite may have been produced by a reaction of albite and mixed-layered micas and clays in their rocks. Merriman and Roberts (1985) invoked several stages that yielded the association muscovite (phengite)-paragonite in metapelites: (1) domination of the $1 \mathrm{M}_{\mathrm{d}}$ polytype in $\mathrm{K}$ - and Na-micas at the lowest temperatures; (2) interstratification of the $1 \mathrm{M}_{\mathrm{d}}$ and $2 \mathrm{M}_{1}$ polytypes of $\mathrm{K}$ - and Na-micas; (3) domi- nance of the $2 \mathrm{M}_{1}$ polytype in muscovite and paragonite at the highest temperatures. Jiang et al. (1990) observed similar features in slates from eastern Pennsylvania, where textural relations imply that the white micas replace detrital smectite-rich clays.

Lee et al. (1984) documented a trend in the textures of intergrown illite and chlorite with increasing metamorphic grade. In shales, illite and chlorite can be intergrown at the scale of individual layers. As the degree of metamorphism increases, the thickness of interlayered packets becomes greater, with individual homogeneous crystals forming with the development of slaty cleavage. Schists that have formed at the lower-temperature limits of the greenschist facies consist of large, homogeneous phases consistent with an approach to equilibrium. Coarser metamorphic micas must have formed by transition from small scale intergrowths at lower grades followed by dissolution and recrystallization to larger separate grains at higher grades. The TEM observations of R.J. Merriman and B. Roberts (personal communication, 1988) confirm that packets of paragonite and phengite similarly coarsen with increase in grade of metamorphism.

The phengite, paragonite and chlorite of this study occur as parallel to subparallel packets of layers that vary in thickness from approximately $20 \mathrm{~nm}$ up to $1 \mu \mathrm{m}$. Given the relations as described above for sequences which cover large ranges of metamorphic grade, it is reasonable to conclude that the sheet silicates of this study have formed through the reaction of original detrital clays that were most probably smectite-rich. Such clays are well known to give rise to white micas as direct replacement products. Ahn and Peacor (1985) found that the trioctahedral component of the detrital clays may yield chlorite intergrown with illite. Ahn et al. (1988) showed that chlorite and illite may form intergrowths of thin packets when initially crystallized during diagenesis of volcanogenic sediments.

Livi et al. (1988) observed intergrowths of paragonite and illite that are either inclined or parallel to the basal planes of micas in anchizone to epizone Alpine black shales. Livi et al. referred to the inclined composition boundaries as being exsolution-like, in part because in the one case of well-documented exsolution in sheet silicates, exsolution lamellae of the sodium biotite and talc are inclined to $\{001\}$ layers (Veblen 1983). All compositional boundaries in the present study are either parallel to $\{001\}$ layers or appear to be inclined only because packets of layers of one composition terminate against those of the other at grain boundaries where $\{001\}$ layers are inclined to one another (Fig. 9). There is therefore no indication of exsolution-derived relations in the observations of this study, and all textures are consistent with an origin through grain growth by dissolution and crystallization.

The fine size of the sheet silicate packets observed in the present study implies that they are in an intermediate stage of development of crystal size, although the phase relations imply that chemical equilibrium has been attained. The question as to why the white micas developed with major $\mathrm{Na}$ or $\mathrm{K}$ components, rather than just 
as phengite, as is more common, is unresolved. The alkali ions may have any of several sources: interlayer cations in smectite (derived in part by exchange with pore fluids during diagenesis), detrital feldspars, or external metamorphic fluids. Because evidence for one or the other of these sources has been destroyed by recrystallization, it is not possible to identify a specific source or to write a specific equation for the reaction.

The chlorite in the present study has $\mathrm{Fe} /(\mathrm{Fe}+\mathrm{Mg})$ ratios ranging from 0.55 to 0.62 and a negative optic sign. These optical properties and $\mathrm{Fe} /(\mathrm{Fe}+\mathrm{Mg})$ ratios are consistent with the plot of refractive indices vs $\mathrm{Fe} /$ $(\mathrm{Fe}+\mathrm{Mg}$ ) of Albee (1962) for pure chlorites that do not contain interlayers of phases such as corrensite, smectites or micas (cf. Shau et al. 1990). Their compositions are also similar to those of chlorites occurring in other blueschist facies rocks (e.g., Moore and Liou 1979; Okay 1980; Cotkin 1987). Based on the TEM images, SAED patterns, and chemical compositions which have only small excesses of $\mathrm{Al}^{\mathrm{VI}}$ over $\mathrm{Al}^{\mathrm{IV}}$, most chlorite in the blueschist is homogeneous and well crystallized.

The anomalous chlorite observed in the present study is chemically similar to some chlorites in sub-greenschist facies rocks which commonly have a large excess of $\mathrm{Al}^{\mathrm{VI}}$ over $\mathrm{Al}^{\mathrm{IV}}$ compared to normal chlorite, and contain some Na, K, and/or Ca (Boles and Coombs 1977; Evarts and Schiffman 1983; Aguirre and Atherton 1987; Laird 1988; Shau et al. 1990). Such compositional anomalies of "chlorite" may be caused by submicroscopic intergrowths or mixed-layering of corrensite, smectites, vermiculite, illite and/or micas (e.g., Shau et al. 1990). The packets of anomalous chlorite observed in this study have compositions that imply the presence of mixedlayering with mica-like layers. They are tentatively interpreted to represent a texture that is a relict of an earlier transition stage, consistent with the overall conclusion concerning lack of textural equilibrium. The chlorite for which no mixed-layering of other phases and no $\mathrm{K}$ or $\mathrm{Na}$ were observed in TEM/AEM analyses also shows a slight excess of $\mathrm{Al}^{\mathrm{VI}}$ that may be due to the presence of vacancies in the octahedral sites (Foster 1962) or the replacement of hydroxyl by oxygen (Albee 1962).

\section{Solvus relationship of paragonite and phengite}

The compositions of coexisting phengite and paragonite in the South Fork Mountain Schist may be used to constrain the phengite-paragonite solvus. Although the electron microprobe analyses of micas in this study were obtained carefully by selecting single-phase areas in BSE images, the limbs of the phengite-paragonite solvus indicated by values of $\mathrm{Na} /(\mathrm{Na}+\mathrm{K})=0.2$ and 0.8 based on the microprobe analyses, are significantly different from those defined by the AEM analyses (Fig. 4). From the compositions of discrete phases as obtained by the AEM analyses, the phengite-paragonite solvus is constrained to values of $\mathrm{Na} /(\mathrm{Na}+\mathrm{K})=<0.02$ and 0.97 at $\mathrm{T}=$ $<200^{\circ} \mathrm{C}$ and $\mathrm{P}<7.4 \mathrm{~kb}$ for this rock. This represents less mutual solid solution between muscovite (or phengite) and paragonite from low-grade metamorphic rocks than was reported previously on the basis of EMPA (e.g., Makanjuola and Howie 1972; Höck 1974; Guidotti 1984; Ahn et al. 1985). The extent of mutual solution between muscovite and paragonite was shown to decrease with increasing phengitic substitution in muscovite (Grambling 1984; Guidotti 1984). Chatterjee and Flux (1986) indicated that the compositions of natural muscovite with little phengitic substitution $(\mathrm{Si} \leq 3.05$ per formula unit) are in reasonable agreement with their calculated muscovite-paragonite solvus whereas those with high phengitic substitution had less paragonite solid solution. The very small extent of mutual solid solution between phengite and paragonite in the South Fork Mountain Schist is thus expected, in terms of the high phengitic substitution of muscovite $(\mathrm{Si}=\sim 3.4$ per formula unit, Table 3$)$, and the low temperature $\left(<200^{\circ} \mathrm{C}\right)$ environment as inferred from the phase equilibria.

\section{Cautions on compositions of fine-grained sheet silicates}

There is a significant difference between average compositions and near end-member compositions of the two micas from EMPA and AEM analyses, respectively. The AEM analyses of submicroscopically intergrown paragonite, phengite, and chlorite suggest that electron microprobe analyses may be averages of the compositions of several intergrown submicron-sized sheet silicates. Therefore, appropriate representative compositions of coexisting paragonite and phengite may be difficult, if not impossible, to obtain with conventional EMPA in low-grade metamorphic rocks, and care should be taken when these compositions are used as indicators of metamorphic grade.

Acknowledgements. We gratefully acknowledge Angela S. Jayko for bringing this occurrence of coexisting paragonite and phengite to our attention and for kindly supplying the rock samples. We appreciate critical reviews of the manuscript by John M. Ferry, Martin Frey, Kenneth J.T. Livi, Klaus Mezger, and Ben A. van der Pluijm. We thank Wei-Teh Jiang, R.J. Merriman, and B. Roberts for their helpful discussions. We also thank the National Museum of Natural History, Smithsonian Institution for providing the sphene standard (B 20360). The assistance of Carl E. Henderson in using the CAMECA microprobe, and of John F. Mansfield and Hildegard G. Hohnke in using the JEOL JEM-2000FX and $100 C X$ STEMs, respectively, at the University of Michigan Electron Microbeam Analysis Laboratory is greatly appreciated. The analytical SEM used in this work was acquired under Grant no. BSR-83-14092, the electron microprobe under Grant no. EAR82-12764, and the STEMs under Grants no. DMR-77-09643 and EAR-87-08276 from the National Science Foundation. The study was supported in part by NSF Grants no. EAR-8107529, EAR-8313236 and EAR-86-04170 to DRP, and EAR-84-08169 and EAR$88-05083$ to EJE.

\section{References}

Aguirre L, Atherton MP (1987) Low-grade metamorphism and geotectonic setting of the Macuchi Formation, western Cordillera of Ecuador. J Metam Geol 5:473-494

Ahn JH, Peacor DR (1985) Transmission electron microscopic study of diagenetic chlorite in Gulf Coast argillaceous sediments. Clays Clay Miner 33:228-236

Ahn JH, Peacor DR, Coombs DS (1988) Formation mechanisms 
of illite, chlorite and mixed-layer illite-chlorite in Triassic volcanogenic sediments from the Southland Syncline, New Zealand. Contrib Mineral Petrol 99:82-89

Ahn JH, Peacor DR, Essene EJ (1985) Coexisting paragonite-phengite in blueschist eclogite: a TEM study. Am Mineral 70:11931204

Ahn JH, Peacor DR, Essene EJ (1986) Cation-diffusion-induced characteristic beam damage in transmission electron microscope images of micas. Ultramicrosc $19: 375-382$

Albee AL (1962) Relationships between the mineral association, chemical composition and physical properties of the chlorite series. Am Mineral 47:851-870

Albee AL, Chodos AA (1965) Microprobe analysis of interlayered muscovite and paragonite, Lincoln Mountain Quadrangle, Vermont (abstr.) Geol Soc Amer Bull 78:2

Ashworth JR, Evirgen MM (1984) Garnet and associated minerals in the southern margin of the Mendcres Massif, southwest Turkey. Gcol Mag 121:323-337

Baltatzis E, Sideris C (1985) Application of the muscovite-paragonite geothermometer to a greenschist facies assemblage from eastern Rhodope Massif, northeastern Greece. Chem Erde $44: 268-272$

Baltatzis E, Wood BJ (1977) The occurrence of paragonite in chloritoid schists from Stonehaven, Scotland. Min Mag 41:211-216

Banno S (1964) Petrologic studies on Sanbagawa crystalline schists in the Bessi-Ino District, Central Sikoku, Japan. J Fac Sci Univ Tokyo 15:203-319

Black PM (1975) Mineralogy of New Caledonian metamorphic rocks. IV. Sheet silicates from the Ouegoa District. Contrib Mineral Petrol 49:269-284

Blencoe JG (1974) An cxperimental study of muscovite-paragonite stability relations. PhD thesis, Stanford Univ

Boles JR, Coombs DS (1977) Zeolite facies alteration of sandstones in the southland syncline, New Zealand. Am J Sci 277:9821012

Brown EH, Forbes RB (1986) Phase petrology of eclogitic rocks in the Faitbanks district, Alaska. Geol Soc Am Mem 164:155167

Brown EH, Ghent ED (1983) Mineralogic and phase relations in the blueschist facies of the Black Butte and Bull Rock areas, northern California Coast Ranges. Am Mineral 68:365-372

Burnham CS, Radoslovich EW (1964) Crystal structures of coexisting muscovite and paragonite. Carnegie Inst Wash Yrbk $63: 232-236$

Carlson WD, Rosenfeld JL (1981) Optical determination of topotactic aragonite-calcite growth kinetics: metamorphic implications. J Geol 89:615-638

Chatterjee ND (1970) Synthesis and upper stability of paragonite. Contrib Mineral Petrol 27:244-257

Chatterjec ND (1973) Low-temperature compatibility relations of the assemblage quartz-paragonite and the thermodynamic status of the phase rectorite. Contrib Mineral Petrol 42:259-271

Chatterjee ND, Flux S (1986) Thermodynamic mixing properties of muscovite-paragonite crystalline solutions at high temperature and pressure, and their geological application. J Petrol $27: 677-693$

Chatterjee ND, Froese E (1975) A thermodynamic study of the join muscovite-paragonite in the system $\mathrm{KAlSi}_{3} \mathrm{O}_{8}-\mathrm{NaAlSi}_{3} \mathrm{O}_{8}-$ $\mathrm{Al}_{2} \mathrm{O}_{3}-\mathrm{H}_{2} \mathrm{O}$. Am Mineral 60:985-993

Cliff $\mathrm{G}$, Lorimer GW (1975) The quantitative analysis of thin specimens. J Microse 103:203-207

Cotkin SJ (1987) Conditions of metamorphism in an early Paleozoic blueschist, schist of Skookum Gulch, northern California. Contrib Mineral Petrol 96:192-200

Cruickshank RD, Ghent ED (1978) Chloritoid-bearing pelitic rocks of the Horsethief Creek Group, southeastern British Columbia. Contrib Mineral Petrol 65:333-339

Droop GTR (1985) Alpine metamorphism in the south-east Tauern Window, Austria 1. P-T variations in space and time. J Metam Geol 3:371-402

Droop GTR, Lombardo B, Pognante U (1990) Formation and distribution of eclogite facies rocks in the Alps. In: Carswell DA (cd) Eclogite facies rocks. Blackie, Glasgow, pp 225-259

Enami M (1983) Petrology of pelitic schists in the oligoclase-biotite zonc of the Sanbagawa metamorphic terrain, Japan. I Metam Geol $1: 141-161$

Essene EJ (1989) The current status of thermobarometry in metamorphic rocks. In: Daly JS, Cliff RA, Yardley BWD (eds) Evolution of metamorphic belts. Geol Soc Lond Spec Pub 43, pp 144

Eugster HP, Albee AL, Bence AE, Thompson JB Jr, Waldbaum DR (1972) The two-phase region and excess mixing properties of paragonite-muscovite crystalline solutions. J Petrol 13:147179

Evarts RC, Schiffman P (1983) Submarine hydrothermal metamorphism of the Del Puerto ophiolite, California. Am J Sci $283: 289-340$

Flux S, Chatterjee ND (1986) Experimental review of the Na-K exchange reaction between muscovite-paragonite crystalline solutions and a 2 molal aqueous $(\mathrm{Na}, \mathrm{K}) \mathrm{Cl}$ fluid. J Petrol 27:665676

Foster MD (1962) Interpretation of the composition and classification of the chlorites. US Geol Surv Prof Pap 414-A:1-33

Franceschelli M, Mellini M, Memmi I, Ricci CA (1986) Fine-scale chlorite-muscovite association in low-grade metapelites from Nurra (NW Sardinia), and the possible misidentification of metamorphic vermiculite. Contrib Mineral Petrol 93:137-143

Frank E (1983) Alpine metamorphism of calcareous rocks across a cross-section in the Central Alps: occurrence and breakdown of muscovite, margarite and paragonite. Schweiz Mineral Petrogr Mitt 63:37-93

Frey M (1969) A mixcd-layer paragonite/phengite of low-grade metamorphic origin. Contrib Mineral Petrol 24:63 65

Frey M (1970) The step from diagenesis to metamorphism in pelitic rocks during Alpine orogenesis. Sediment 15:261-279

Frey M (1978) Progressive low-grade metamorphism of a black shale formation, central Swiss Alps, with special reference to pyrophyllite and margarite bearing assemblages. J Petrol 19:95-135

Ghent ED, Stout MZ, Black PM, Brothers RN (1987) Chloritoidbearing rocks associated with blueschists and eclogites, northern New Caledonia. J Metam Geol 5:239-254

Gil Ibarguchi JI, Ortega Girones E (1985) Petrology, structure and geotectonic implications of glaucophane-bearing eclogites and related rocks from the Malpica Tuy (MT) unit, Galicia, northwest Spain. Chem Geol 50:145-162

Godard G (1988) Petrology of some eclogites in the Hercynides: the eclogites from the southern Armorican Massif, France. In: Smith DC (ed) Eclogites and eclogite-facies rock, Developments in Petrology, vol 12, pp 451-519

Grambling JA (1984) Coexisting paragonite and quartz in sillimanitic rocks from New Mexico. Am Mineral 69:79-87

Green NL, Usdansky SI (1986) Toward a practical plagioclasemuscovite thermometer. Am Mineral 71:1109-1117

Guidotti CV (1984) Micas in metamorphic rocks. In: Bailey SW (ed) Micas (Reviews in mineralogy, vol 13), Mineralogical Society of America, Washington DC, pp 357-467

Guitard G (1987) Coexistence de la paragonite et de la muscovite dans les metamorphites hercyniens des Pyrenees orientales franco-espagnoles. Compte Rendu Acad Sci II 305:783-786

Henley KJ (1970) Application of the muscovite-paragonite geothermometcr to a staurolite-grade schist from Sulitjelma, north Norway. Mineral Mag 37:693-704

Höck V (1974) Cocxisting phengite, paragonite and margarite in metasediments of the Mittlere Hohe Tauern, Austria. Contrib Mineral Petrol 43:261-273

Hoffer E (1978) On the "late" formation of paragonite and its breakdown in pelitic rocks of the southern Damara Orogen (Namibia). Contrib Mineral Petrol 67:209-219

Holland TJB (1979) Experimental determination of the reaction paragonite $=$ jadeite + kyanite $+\mathrm{H}_{2} \mathrm{O}$ and thermodynamic data for part of the system $\mathrm{Na}_{2} \mathrm{O}-\mathrm{Al}_{2} \mathrm{O}_{3}-\mathrm{SiO}_{2}-\mathrm{H}_{2} \mathrm{O}$, with application 
to eclogites and blueschists. Contrib Mineral Petrol 68:293301

Holland TJB (1980) The reaction albite $=$ jadeite + quartz determined experimentally in the range $600-1200^{\circ} \mathrm{C}$. Am Mineral 65:129-134

Holland TJB (1988) Preliminary phase relations involving glaucophane and applications to high pressure petrology: new heat capacity and thermodynamic data. Contrib Mineral Petrol 99:134-142

Holland TJB, Powell R (1990) An enlarged and updated internally consistent thermodynamic dataset with uncertainties and correlations: the system $\mathrm{K}_{2} \mathrm{O}-\mathrm{Na}{ }_{2} \mathrm{O}-\mathrm{CaO}-\mathrm{MgO}-\mathrm{MnO}-\mathrm{FeO}-\mathrm{Fe}_{2} \mathrm{O}_{3}$ $\mathrm{Al}_{2} \mathrm{O}_{3}-\mathrm{TiO}_{2}-\mathrm{SiO}_{2}-\mathrm{C}-\mathrm{H}_{2}-\mathrm{O}_{2}$. J Metam Geol 8:89-124

Jayko AS, Blake MC Jr, Brothers RN (1986) Blueschist metamorphism of the eastern Franciscan belt, Northern California. Geol Soc Am Mem 164:107-123

Jiang W-T, Peacor DR, Merriman RJ, Roberts B (1990) STEM study of mixed-layer illite/smectite formed as a replacement product of authigenic illite. Clays Clay Miner (in press)

Katagas C, Baltatzis E (1980) Coexisting celadonitic muscovite and paragonite in chlorite zone metapelites. $\mathrm{N} \mathrm{Jb}$ Mineral $\mathrm{Mh}$ 1980:206-244

Kramm U (1980) Muskovit-Paragonit Phasenbeziehungen in niedriggradig metamorphen Schiefern des Venn-Stavelot Massivs, Ardennen. Tscherm Mineral Petrogr Mitt 27:153-167

Laird J (1988) Chlorites: metamorphic petrology. In: Bailey SW (ed) Hydrous phyllosilicates (Reviews in mineralogy, vol 19), Mineralogical Society of America, Washington DC, pp 405-453

Laird J, Albee AL (1981) Pressure, temperature and time indicators in mafic schists: their application to reconstructing the polymetamorphic history of Vermont. Am J Sci 281:127-175

Lee JH, Peacor DR, Lewis DD, Wintsch RP (1984) Chlorite-illite/ muscovite interlayered and interstatified crystals: a TEM/ STEM study. Contrib Mineral Petrol 88:372-385

Livi KJT, Veblen DR, Ferry JM (1988) Electron microscope study of anchizone and epizone metamorphosed shales from the central Swiss Alps. Geol Soc Am, Abst Prog 20: A244

Makanjuola AA, Howie RA (1972) The mineralogy of the glaucophane schists and associated rocks from lle de Groix, Brittany, France. Contrib Mineral Petrol 35:83-118

Massonne HJ, Schreyer W (1987) Phengite geobarometry based on the limiting assemblage with K-feldspar, phlogopite and quartz. Contrib Mineral Petrol 96:212-224

Menot R-P, Seddoh KF (1985) The eclogites of Lato Hills, South Togo, West Africa: relics from the early tectonometamorphic evolution of the Pan African orogeny. Chem Geol 50:313-330

Merriman RJ, Roberts B (1985) A survey of white mica crystallinity and polytypes in pelitic rocks of Snowdonia and Llyn, North Wales. Mineral Mag 49:305-319

Mohr DW, Newton RC (1983) Kyanite-staurolite metamorphism in sulfidic schists of the Anakeesta Formation, Great Smoky Mountains, North Carolina. Am J Sci 283:97-134

Moore DE, Liou JG (1979) Mineral chemistry of some Franciscan blueschist facies metasedimentary rocks from the Diablo Range, California. Geol Soc Am Bull 90:1737-1781

Mottana A, Carswell DA, Chopin C, Oberhänsli R (1990) Eclogite facies mineral parageneses. In: Carswell DA (ed) Eclogite facies rocks, Blackie, Glasgow, pp 14-52
Mposkos E (1989) High-pressure metamorphism in gneisses and pelitic schists in the east Rhodope zone (N. Greece). Mineral Petrol $41: 25-39$

Mposkos E, Perdikatzis V (1981) The paragonite-chloritoid schists of the southwest region of Mount Kerkis, Samos (Greece). N Jb Mineral Abh 142;292-308

Munha J, Ribeiro A, Ribeiro ML (1984) Blneschists in the Iberian Variscan Chain (Tras-os-Montes: NE Portugal). Comun Serv Geol Portugal 70:31-53

Nakamura H, Kihara K (1977) Coexistence of $2 \mathrm{M}_{1}$ and $3 \mathrm{~T}$ muscovites and paragonites in low grade metamorphic rocks of the Sanbagawa metamorphic belt, Japan. Mineral J 8:1343-1348

Okay AI (1980) Mineralogy, petrology, and phase relations of glaucophane-lawsonite zone blueschists from the Tavsanli region, northwest Turkey. Contrib Mineral Petrol 72:243-255

Okrusch M, Seidel E, Davis EN (1978) The assemblage jadeitequartz in the glaucophane rocks of Sifnos (Cyclades Archipelago, Greece). N Jb Mineral Abh 132:284-308

Okuyama-Kusunose Y (1985) Margarite-paragonite-muscovite asemblages from the low-grade metapelites of the Tono metamorphic aureole, Kitakami Mountains, northeast Japan. J Japan Assoc Mineral Petrol Econ Geol 80:515-525

Pascal ML, Roux J (1985) K-Na exchange equilibria between muscovite-paragonite solid solution and hydrothermal chloride solutions. Mineral Mag 49:515-521

Pe-Piper G (1985) Dioctahedral micas in Triassic metavolcanic rocks of western Greece. Can Mineral 23:597-608

Ridley S (1984) Evidence of a temperature-dependent "blueschist" to "eclogite" transformation in high-pressure metamorphism of metabasic rocks. J Petrol 25:852-870

Sandrone R, Leardi L, Rossetti P, Compagnoni R (1986) P-T conditions for the eclogitic reequilibration of the metaophiolites from Val d'Ala di Lanzo (internal Piemontese zone, Western Alps). J Metam Geol 4:161-178

Schliestedt M, Okrusch M (1988) Meta-acidites and silicic metasediments related to eclogites and glaucophanites in northern Sifnos, Cycladic Archipelago, Greece. In: Smith DC (ed) Eclogites and eclogite-facies rocks, Developments in Petrology, vol 12, pp 291-334

Shau Y-H, Peacor DR, Essene EJ (1990) Corrensite and mixedlayer chlorite/corrensite in metabasalt from northern Taiwan: TEM/AEM, EMPA, XRD, and optical studies. Contrib Mineral Petrol 105:123-142

Thompson AB, Lyttle PT, Thompson JB Jr (1977) Mineral reactions and A-Na-K and A-F-M facies types in the Gassetts Schist, Vermont. Am J Sci 277:1124-1151

Van der Pluijm BA, Lee JH, Peacor DR (1988) Analytical electron microscopy and the problem of potassium diffusion. Clays Clay Miner 36:498-504

Veblen DR (1983) Exsolution and crystal chemistry of the sodium mica wonesite. Am Mineral 68:554-565

Velde B (1965) Phengite micas: synthesis, stability and natural occurrence. Am J Sci 263:886-913

Zen E, Albee AL (1964) Coexistent muscovite and paragonite in pelitic schists. Am Mineral 49:904-925

Editorial responsibility: J. Ferry 